\title{
Chemical treatment of wastewater from flue gas desulphurisation
}

\author{
Iwona Pasiecznik ${ }^{1, *}$, Włodzimierz Szczepaniak ${ }^{1}$ \\ ${ }^{1}$ Wroclaw University of Science and Technology, Faculty of Environmental Engineering, Wybrzeze \\ Wyspianskiego 27, 30-370 Wroclaw, Poland
}

\begin{abstract}
The article presents results of laboratory tests of removing boron and arsenium from non-ideal solutions using double-layered magnesium/aluminium hydroxides $(\mathrm{Mg} / \mathrm{Al}$ Double-Layered Hydroxide DLH) produced with nitrate-chloride method. In research, wastewater from an installation for flue gas desulfurization was examined. Double-layered hydroxides are perfect absorbents for anionic compounds. The research proved high effectiveness of preparation with reference to arsenium, as well as confirmed the effect of presence of sulfatic and arsenate ions on the effectiveness of boron removal. On the basis of research on absorption kinetics a theoretical dose of $\mathrm{DLH} / \mathrm{NO}_{3}-\mathrm{Cl} / \mathrm{M}$ preparation was calculated and compared with a dose that ensures emimination of boron below the limit standarized by the national regulations. Application of double-layered magnesium/aluminium hydroxides for boron elimination from industrial wastewater requires significantly higher doses of preparation than those calculated in model investigations. It is due to the priority of removal of multivalent ions, such as sulfatic, arsenate or phosphate ions, by $\mathrm{DLH} / \mathrm{NO}_{3}-\mathrm{Cl} / \mathrm{M}$.
\end{abstract}

\section{Introduction}

The composition of wastewaters emerging during production of non-ferrous metals, including copper, is significantly diverse. They consist almost all substances, both in soluble form or as suspensions. They are mostly neutral inorganic materials, soluble components of raw materials, dusts, additives, auxiliary agents, etc. [1].

Copper production in Poland is performed using technologies of shaft furnace and suspension furnace. In the shaft process copper concentrate is remelted to copper stone, then subjected to convertoring. Gases from shaft furnace (so-called furnace top gases) are subjected to wet dust cleaning and directed to heat and power generating plant, for energetic use. Gases from heat and power generating plant are desulfurized in flue-gas desulfurizing installation. Wastewaters from this process contain significant amounts of heavy metals and boron. Sludges generated in the process of wet dust cleaning are lead-bearing raw material temporarily deposited in landfills in the area of metal-works. It was found that eluates from such landfills are characterized by high concentrations of boron

\footnotetext{
* Corresponding author: iwona.pasiecznik@pwr.edu.pl
} 
and arsenium. Scheme of technological process of refined copper production is presented in Figure 1 [1].

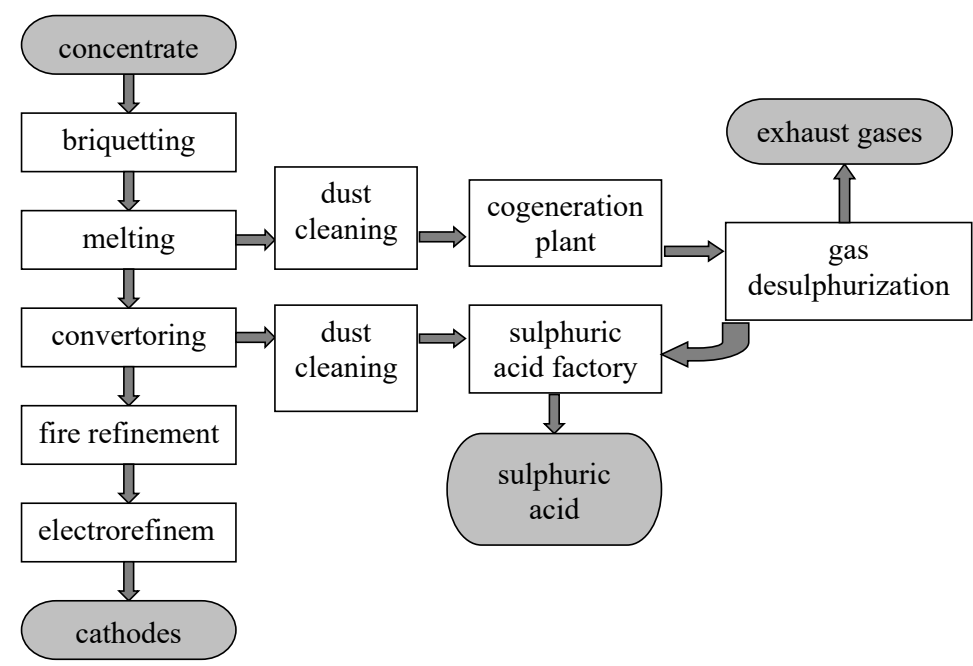

Fig. 1. Scheme of technological process of refined copper production [1].

In case of the wastewater plant in one of Polish copper mills, an additional source of boron in influent wastewater is a temporary landfill of lead-bearing concentrate and a slagheap. Drainage and rain waters from these objects flow into a detention-sedimentation tank, and then to the wastewater plant. Boron content in draining and rain water from the lead-bearing concentrates landfill and from the slagheap varies from a dozen or so to a few hundred $\mathrm{mg} / \mathrm{L}$. Limiting amounts of water flowing into the tank and wastewater plant is difficult to achieve from the technological point of view, therefore it is impossible to lower the boron concentration in processed wastewater leaving the wastewater plant by lowering boron load in raw wastewater [1].

The problem of eliminating boron from wastewater is connected, among others, with processing wastewater from the copper industry. It should be considered as an important issue, especially in regions having a main source of boron penetration into the environment. Lack of effective method of processing waste having high boron concentration is one of the main causes of high concentration of this element in nearby surface waters. Wastewater disposed to the environment causes contamination of potable water and water used for irrigation of crops in which boron concentration should be limited for health reasons [2]. Due to this, reduction of boron concentration in industrial wastewater below the values defined by regulations is necessary.

Boron can be eliminated from water or wastewater using various technologies, but most of the methods proposed have limitations and can be used only conditionally. Chemical precipitation may be used for elimination of boron but it requires relatively high levels of $\mathrm{pH}(\mathrm{pH}>9)$, that causes high saltness of solution and generates significant amounts of sludge [3-7]. Besides, high costs of chemical substances, as well as the costs of sludge utilization and disposal make this process of boron elimination inadvisable in many cases $[8,9]$. Activated carbon, impregnated activated carbon and silty materials, due to their high sorption capacity, proved to be ineffective and unprofitable when used in a large scale [10, 11]. A liquid-liquid extraction technology offers a possibility of retrieving boron for market purposes from industrial wastewater, but it is only profitable when the initial concentration of boron in solution is at least $3 \mathrm{~g} / \mathrm{L}[12,13]$. Ion-exchange resin Amberlite IRA 743 shows excellent effectiveness of borate ion removal, but high costs of technological system, as 
well as costs of regeneration, considerably limit its use [14, 15]. Reverse osmosis and electrodialysis allow for effective boron removal but these processes require increasing $\mathrm{pH}$ of influent solution above $9 \mathrm{pH}$, that causes high potential with colloidal scaling and fouling, therefore limiting application of these technologies for boron removal from wastewater [16]. Obtaining the boron concentration value in potable water at the level normalized by WHO $(0.5 \mathrm{mg} / \mathrm{L})$ requires application of multistage RO system [17]. Numerous difficulties and economical disadvantages of processes mentioned above were the impulse for new research works oriented on establishing effective and economically reasonable methods of boron removal, since according to the World Health Organization [18], boron is an element that cannot be removed using conventional methods of water and wastewater processing. One of recently tested technologies of boron removal are doublelayered hydroxides [19].

Double-layered hydroxides (DLH) are a kind of synthetic silty materials with a structure described by the formula $\mathrm{M}(\mathrm{II})_{1-\mathrm{x}} \mathrm{M}(\mathrm{III})_{\mathrm{x}}(\mathrm{OH})_{2}\left(\mathrm{~A}^{n-}\right)_{\mathrm{x} / \mathrm{n}} \bullet m \mathrm{H}_{2} \mathrm{O}$, where both bivalent $\mathrm{M}(\mathrm{II})$ and trivalent $\mathrm{M}(\mathrm{III})$ cations form positively charged layers. These layers remain in equilibrium with $\mathrm{A}^{n-}$ anions in hydrated interlayer areas [19]. Removal of boron/borates or arsenate ions may be done by exchange with ions from the hydrated layer or by complexation of hydroxyl groups on the surface of DLH layers. Double-layered hydroxides are considered excellent adsorbents of anionic compounds [20]. Numerous studies showed that DLH are effective in processes of remediation of land-water environment, especially if anionic contaminants of water are concerned [21-23].

Double-layered $\mathrm{Mg} / \mathrm{Al}$ hydroxides have high boron removal capacity and hold promise of high effectiveness in boron removal from waters and wastewaters. Application of DLH allows to remove this element effectively from solutions having its concentration below $50 \mathrm{mg} / \mathrm{L}$, and down to the limits recommended by the WHO in potable water $(<0.5 \mathrm{mg} / \mathrm{L})$ [18].

The aim of laboratory studies was to determine the effectiveness of removing borate and arsenate ions from wastewater generated in flue-gas desulfurizing installation, using magnesium/aluminium hydroxide obtained with nitrate-chloride salts.

\section{Materials and methods}

Preparatics of original DLH substance, prepared using magnesium nitrate(V), aluminium chloride and sodium hydroxide, is described in detail in literature [19]. Detailed research performed with the preparation mentioned above led to some appropriate modifications of original DLH preparation, and in consequence obtaining stable preparation, efficiently removing boron and avoiding significant saltness of solution, denoted as $\mathrm{DLH} / \mathrm{NO}_{3}-\mathrm{Cl} / \mathrm{M}$ in subsequent text [24]. The chemical formula of prepared double-layered magnesium/aluminium hydroxide $\left(\mathrm{DLH} / \mathrm{NO}_{3}-\mathrm{Cl} / \mathrm{M}\right)$, obtained using chloride-nitrate method, differs from the DLH formula given in literature: $\mathrm{Mg}_{2} \mathrm{AlNa}_{1,4}(\mathrm{OH})_{7,57} \mathrm{Cl}_{0,03}\left(\mathrm{NO}_{3}\right)_{0,8} \cdot x \mathrm{H}_{2} \mathrm{O}$ [19], mostly by the number of sodium and chloride ions.

The research was conducted on wastewater from the flue-gas desulfurizing installation in one of Polish copper mills. The composition of raw wastewater is presented in Table 1 . Wastewaters from flue-gas desulfurizing installations are strongly acidic ( $\mathrm{pH}$ about 1.7) and contain high concentrations of heavy metals.

$\mathrm{DLH} / \mathrm{NO}_{3}-\mathrm{Cl} / \mathrm{M}$ was added to wastewater from the flue-gas desulfurization installation in amounts of $1.5-50 \mathrm{~g} / \mathrm{L}$. The first series of tests was performed without modification of the wastewater $\mathrm{pH}$, whereas in the second series for the same doses of double-layered magnesium/aluminium hydroxide the initial $\mathrm{pH}$ of wastewater was adjusted to 6.0-7.0 with sodium hydroxide $(20 \% \mathrm{NaOH})$. A mixture of wastewater and $\mathrm{DLH} / \mathrm{NO}_{3}-\mathrm{Cl} / \mathrm{M}$ was mixed 
for 1 hour applying the rotary speed of $300-400 \mathrm{rpm}$, then concentrations of boron and arsenium were determined in supernatant separated by percolation. Time of contact of the preparation with solution was assigned on the basis of earlier research [24] that showed that effectiveness of boron removal increases with time of contact of solution with $\mathrm{DLH} / \mathrm{NO}_{3}-\mathrm{Cl} / \mathrm{M}$, and at the same time it is worth stressing that straight majority of boron was sorbed during the first 40-60 minutes of the process.

Table 1. Average composition of wastewater from flue-gas desulfurizing installation.

\begin{tabular}{|c|c|c|c|}
\hline Kind of contaminant & $\begin{array}{c}\text { Average } \\
\text { concentration } \\
{[\mathbf{m g} / \mathbf{L}]}\end{array}$ & Kind of contaminant & $\begin{array}{c}\text { Average } \\
\text { concentration } \\
{[\mathbf{m g} / \mathbf{L}]}\end{array}$ \\
\hline Boron & 3.69 & Zinc & 477 \\
\hline Arsenium & 143 & Iron & 2.27 \\
\hline Cadmium & 124 & Mercury & 1.556 \\
\hline Copper & 0.767 & Sulphates & 2493 \\
\hline Lead & 3.16 & Nitrates & 3.5 \\
\hline Nickel & 0.096 & Dissolved substances & 7426 \\
\hline Chromium & 0.101 & Dry residue & 7356 \\
\hline Cobalt & 0.038 & Suspensions & 70 \\
\hline
\end{tabular}

\section{Results and discussion}

Double-layered hydroxides introduced into model solutions prepared with distilled water, due to their chemical properties, affect the reaction of solutions. They are hydroxide preparations, and that causes that solutions gain an equilibrium about a $\mathrm{pH}$ value of 10 . Therefore, the $\mathrm{pH}$ value might have a significant effect on boron ions removal. Due to this, tests with non-ideal solutions were performed in two variants: without initial $\mathrm{pH}$ adjustment in wastewater, and with its adjustment to the range of $6.0-7.0$ (the range was determined for model solutions showing the most efficient boron ions removal [24]). The results obtained are presented in Tables 2 and 3.

Table 2. Results of boron and arsenium removal from wastewater generated in the installation for flue-gas desulfurization, for various doses of $\mathrm{DLH} / \mathrm{NO}_{3}-\mathrm{Cl} / \mathrm{M}$, without initial $\mathrm{pH}$ adjustment in wastewater.

\begin{tabular}{|c|c|c|c|c|c|c|}
\hline Dose of DLH/NO${ }_{3}-\mathrm{Cl} / \mathrm{M}[\mathrm{g} / \mathrm{L}]$ & 5 & 10 & 20 & 30 & 50 & 70 \\
\hline Wastewater pH & 1.7 & 1.7 & 1.7 & 1.7 & 1.7 & 1.7 \\
\hline pH after addition of DLH/NO ${ }_{3}-\mathrm{Cl} / \mathrm{M}$ & 5.4 & 5.51 & 6.71 & 7.35 & 9.14 & 9.53 \\
\hline Wastewater $\mathrm{pH}$ after the process & 6.97 & 7.11 & 8.88 & 9.24 & 10.99 & 11.2 \\
\hline $\begin{array}{c}\text { Boron concentration after the } \\
\text { process }[\mathrm{mg} / \mathrm{L}]\end{array}$ & 2.37 & 2.17 & 1.94 & 1.63 & 1.57 & 0.89 \\
\hline $\begin{array}{l}\text { Arsenium concentration after the } \\
\text { process }[\mathrm{mg} / \mathrm{L}]\end{array}$ & 138 & 126 & 45.8 & 34 & 29.6 & 11.1 \\
\hline
\end{tabular}

Results of the research are presented graphically in Figs. 2 and 3. On the Figure 3, showing the effect of $\mathrm{DLH} / \mathrm{NO}_{3}-\mathrm{Cl} / \mathrm{M}$ dose on the final arsenium concentration in wastewater (with and without $\mathrm{pH}$ adjustment) it is clearly visible that $\mathrm{pH}$ of wastewater had a significant effect on arsenium ions removal. The preparation sorbed arsenate ions far better from wastewater with initial $\mathrm{pH}$ adjusted. Differences in effectiveness of arsenium removal were even as great as $80 \%$, for the same doses of double-layered hydroxides. It should also be noted that the preparation studied, despite of high concentration of contaminants in wastewater from flue-gas desulfurization, removed arsenate ions from solutions with high effectiveness. Arsenium was sorbed by $\mathrm{DLH} / \mathrm{NO}_{3}-\mathrm{Cl} / \mathrm{M}$ even in $99 \%$. 
Table 3. Results of boron and arsenium removal from wastewater generated in the installation for flue-gas desulfurization, for various doses of $\mathrm{DLH} / \mathrm{NO}_{3}-\mathrm{Cl} / \mathrm{M}$, with initial $\mathrm{pH}$ adjustment in wastewater.

\begin{tabular}{|c|c|c|c|c|c|c|}
\hline Dose of DLH/NO${ }_{3}-\mathrm{Cl} / \mathrm{M}[\mathrm{g} / \mathrm{L}]$ & 5 & 10 & 20 & 30 & 50 & 70 \\
\hline Wastewater pH & 1.7 & 1.7 & 1.7 & 1.7 & 1.7 & 1.7 \\
\hline pH adjusted with $20 \% \mathrm{NaOH}$ & 6.05 & 5.9 & 6.86 & 6.41 & 6.23 & 6.25 \\
\hline $\mathrm{pH}$ after addition of $\mathrm{DLH} / \mathrm{NO}_{3}-\mathrm{Cl} / \mathrm{M}$ & 7.3 & 7.71 & 9.26 & 9.68 & 10.0 & 10.45 \\
\hline Wastewater $\mathrm{pH}$ after the process & 9.2 & 9.48 & 11.19 & 11.32 & 11.50 & 11.64 \\
\hline $\begin{array}{c}\text { Boron concentration after the } \\
\text { process }[\mathrm{mg} / \mathrm{L}]\end{array}$ & 2.48 & 1.95 & 1.86 & 1.83 & 1.56 & 0.93 \\
\hline $\begin{array}{c}\text { Arsenium concentration after the } \\
\text { process }[\mathrm{mg} / \mathrm{L}]\end{array}$ & 67 & 18.3 & 10.7 & 8.3 & 5.2 & 1.1 \\
\hline
\end{tabular}

Arsenium is a very toxic element and its concentrations even so small as a few $\mathrm{mg} / \mathrm{L}$ may be very dangerous. The acceptable concentration of arsenium in potable water in Poland, according to directives of the World Health Organization [18] and a directive of Health Minister [2], is $0.01 \mathrm{mg} / \mathrm{L}$. Acceptable arsenium concentration in wastewater dumped to waters or soil [25] is $0.1 \mathrm{mg} / \mathrm{L}$ for all kinds of industrial wastewater, except wastewater from the glass industry, where the acceptable limit was established at the level of $0.3 \mathrm{mg} / \mathrm{L}$. Tests on model solutions proved that even small amounts of arsenium (concentrations ratio $\mathrm{As}^{+5} / \mathrm{B}=1: 5$ ) lower the effectiveness of boron removal by about $30 \%$ [24]. The effectiveness of boron removal with nitrate-chloride preparation was changing exponentially with the increase of As concentration. Arsenate ions significantly limited borate ions removal [24] and initial adjustment of $\mathrm{pH}$ in solution did not make any difference. Borate ions at the initial $\mathrm{pH}$ of 1.7 , as well as after its adjustment to 6.0-7.0 were removed with the same effectiveness. These results confirm that the presence of other ions in solution made a competition in removing borate ions by DLH preparation [24]. Multivalent ions were the first exchanged with anions from hydrated layer of doublelayered hydroxides. Therefore the initial stages of wastewater processing should be planned (knowing their elemental composition) in a manner that would allow to eliminate other contaminants first.

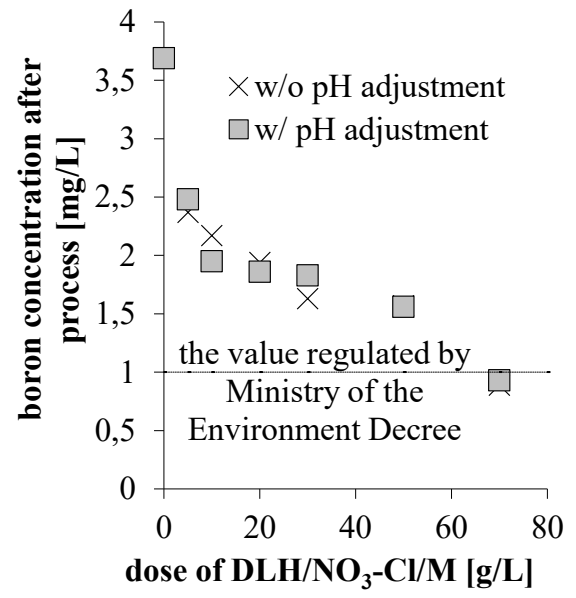

Fig. 2. Relation between final boron concentration in wastewater from Solinox and the dose of $\mathrm{DLH} / \mathrm{NO}_{3}-\mathrm{Cl} / \mathrm{M}$; wastewater $\mathrm{pH}$ adjusted.

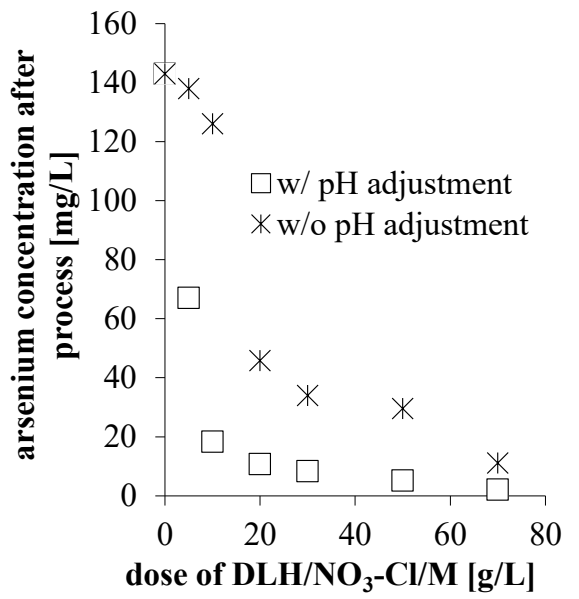

Fig. 3. Relation between final arsenium concentration in wastewater from Solinox and the dose of $\mathrm{DLH} / \mathrm{NO}_{3}-\mathrm{Cl} / \mathrm{M}$; wastewater $\mathrm{pH}$ adjusted. 


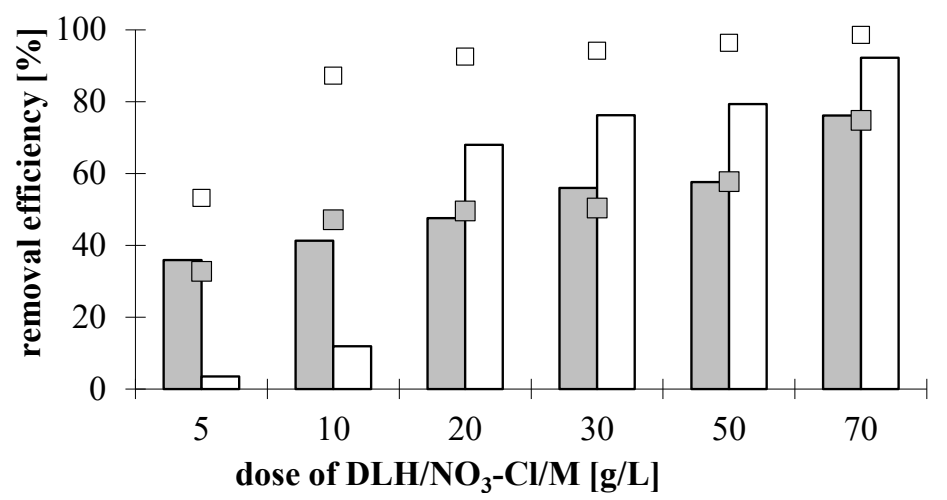

$\square$ boron w/o pH adjustment $\square$ arsenium w/o pH adjustment
$\square$ boron w/ pH adjustment $\quad \square$ arsenium w/ pH adjustment

Fig. 4. Comparison of effectiveness of boron and arsenium removal from wastewater generated in flue-gas desulfurization installation depending on the dose of $\mathrm{DLH} / \mathrm{NO}_{3}-\mathrm{Cl} / \mathrm{M}$, with and without initial $\mathrm{pH}$ adjustment.

On the basis of adsorption kinetics [24] a theoretical dose of DLH/NO $3-\mathrm{Cl} / \mathrm{M}$ was determined, using the formula [26]:

$$
x=\frac{x_{m} b C}{1+b C}
$$

where: $x$ - amount of substance adsorbed, per unit of adsorbent $[\mathrm{mg} / \mathrm{g}]$

$$
x=\frac{\left(C_{O}-C\right)}{m}
$$

$m$ - dose of adsorbent $[\mathrm{g} / \mathrm{L}] ; C$ - adsorbate concentration after the process $[\mathrm{mg} / \mathrm{L}]$; $C_{0}$ - initial adsorbate concentration $[\mathrm{mg} / \mathrm{L}] ; x_{m}$ - capacity of monolayer (maximum number of ions that can be retained by the unit mass of adsorbent $[\mathrm{mg} / \mathrm{g}] ; b$ - parameter of Langmuir's isotherm $[\mathrm{L} / \mathrm{mg}]$.

The basis for calculation of the dose of double-layered magnesium/aluminium hydroxide was the boron adsorption isotherm. The process of boron adsorption on the surface of $\mathrm{DLH} / \mathrm{NO}_{3}-\mathrm{Cl} / \mathrm{M}$ was properly described by Langmuir's model. It was confirmed by a high value of determination coefficient $\mathrm{R}^{2}=0.9996$, as well as the mass of substance adsorbed per unit mass of adsorbent, almost identical to the calculated value [24]. For boron concentration in wastewater of $3.69 \mathrm{mg} / \mathrm{L}$ and required concentration after the process $(1.0 \mathrm{mg} / \mathrm{L})$, a theoretical dose of $\mathrm{DLH} / \mathrm{NO}_{3}-\mathrm{Cl} / \mathrm{M}$ was $27.0 \mathrm{~g} / \mathrm{L}$.

A dose of $\mathrm{DLH} / \mathrm{NO}_{3}-\mathrm{Cl} / \mathrm{M}$ that allowed to remove boron below $1.0 \mathrm{mg} / \mathrm{L}$ was determined as $70 \mathrm{~g} / \mathrm{L}$. On the ground of obtained results it was concluded that the calculated dose proved to be too small to remove boron below the level of $1.0 \mathrm{mg} / \mathrm{L}$. It might be caused by the fact that a theoretical dose was calculated for model solutions, whereas the composition of wastewater tested (extremely high concentrations of heavy metals) might deteriorate boron removal on the surface of double-layered magnesium/aluminium hydroxide, due to presence of other ions hindering the process of boron removal (especially arsenate [24] and sulphate ions [27, 28]).

Technology of processing wastewater generated in described copper mill, based on neutralization and chemical precipitation of contaminants, enables processing wastewater 
with the effectiveness of $90 \%$ and boron removal in $50 \%$, that is not always sufficient to achieve a concentration of boron in processed waste at the level below $1.0 \mathrm{mg} / \mathrm{L}$ [1]. Processed wastewater is directed from the wastewater plant to nearby stream, where boron concentrations often exceed values normalized by the national regulations. Boron concentration downstream from the wastewater outlet increases by about $29 \%-63 \%$ compared with water upstream the wastewater plant [1]. Application of double-layered magnesium/aluminium hydroxides as a technology of wastewater post-processing ensures effective removal of borate ions after previous processes of chemical precipitation.

\section{Conclusions}

Removal of boron from non-ideal solutions and achieving its concentrations below the limits established in regulations requires far greater doses of double-layered magnesium/aluminium hydroxides than a theoretical dose calculated for model solutions.

High concentrations of contaminants in water or wastewater make the process of boron removal difficult. This is due to the priority of removing multivalent ions before borate ions by $\mathrm{DLH} / \mathrm{NO}_{3}-\mathrm{Cl} / \mathrm{M}$.

$\mathrm{DLH} / \mathrm{NO}_{3}-\mathrm{Cl} / \mathrm{M}$ preparation removes arsenate ions from solutions very effectively and it could be applied for co-removal of arsenium from water solutions.

In non-ideal solutions, characterized by high concentrations of contaminants, double-layered magnesium/aluminium hydroxides could be used in post-processing of waters and wastewaters, both for boron and arsenium removal.

\section{References}

1. M. Mańczak, M. Balbierz, A. Jaksik, Appendix to legal agreement delimiting the special ways of water usage in the area of dumping wastewater to the Biatynia stream by the 'Energetyka' Co. in Lubin, Report 12/2005 - Institute of the Environmental Engineering, Wrocław Technical University, Wrocław (2005) (in Polish)

2. Health Minister Decree of 13.11.2015 r., Dz.U. 2015, poz. 1989 (2015) (in Polish)

3. I. Pasiecznik, M. Mańczak, Gaz, Woda i Technika Sanitarna 83, 5, 12-13 (2009) (in Polish)

4. Y. Xu, J-Q. Jiang, Ind. Eng. Chem. Res. 47, 16-24 (2008)

5. A.G. Pervov, A.P. Andrianov, R.V. Efremov, A.V. Desyatov, A.E. Baranov, Desalination 157, 377-384 (2003)

6. A. Withers, Desalination 179, 11-24 (2005)

7. I. Pasiecznik, M. Mańczak, Forum Eksploatatora 6, 40-41 (2007) (in Polish)

8. J.R. Sims, F.T. Bingham, Soil Sci. Soc. Am. Proc. 32, 364-369 (1968)

9. R. Kern, R.G. Gast, Soil Sci. Soc. Am. J. 47, 1116-1121 (1983)

10. L.V. Rajakovic, M.D. Ristic, Carbon 34, 6, 769 (1996)

11. J. Kluczka, J. Ciba, J. Trojanowska, M. Zolotajkin, M. Turek, P. Dydo, En. Viron. Prog. 26, 1, 71 (2007)

12. D.E. Garrett, F.J. Weck, A.J. Marsh, H.R. Foste, U.S. Patent 3,111,383, November 19, (1963)

13. R.R. Grinstead, Ind. Eng. Chem. Prod. Res. De. Vel. 11, 454 (1972)

14. M.O. Simonnot, C. Castel, M. Nicolai, C. Rosin, M. Sardin, H. Jauffret, Water Res. 34, 1,109 (2000) 
15. Y. Xiao, B.Y. Liao, W.G. Liu, Y. Xiao, G.H. Swihart, Chin. J. Chem. 21, 1073 (2003)

16. M.R. Pastor, A.F. Ruiz, M.F. Chillo'n, D.P. Rico, Desalination 140, 145-152 (2001)

17. K. Fukunaga, M. Matsukata, K. Ueyama, S. Kimura, Membrane 22, 4, 211 (1997)

18. World Health Organization, Guidelines for Drinking Water Quality, $4^{\text {th }}$ ed., Geneva (2011)

19. J.Q. Jiang, Y. Xu, J. Simon, K. Quill, K. Shettle, Ind. Eng. Chem. Res. 46, 4577 (2007)

20. Y.T. Liu, T.Y. Chen, M.K. Wang, P.M. Huang, P.N. Chiang, J.F. Lee, Applied Clay Science 48, 485-491 (2010)

21. F. Konvanda, E. Kovacsova, D. Kolousek, Collect. Czech. Chem. Commum, 64, 1517-1528 (1999)

22. Y. Seida, Y. Nakano, Water Res. 36, 1306-1312 (2002)

23. R. Nomura, T. Mori, E. Kanezaki, T. Yaburani, Int. J. Mod. Phys. B. 17, 1458-1463 (2003)

24. I. Pasiecznik, Doctoral Thesis, Application of double-layered magnesium/aluminium hydroxides for removal of boron from solutions (Institute of the Environmental Engineering, Wrocław Technical University, Wrocław, 2010) (in Polish)

25. Minister of Environmetal Protection Decree of 18.11.2014 r., Dz. U. 2014, poz. 1800 (2014) (in Polish)

26. W. Adamski, Modeling of water purification systems (Polish Scientific Publishers PWN, Warszawa, 2002) (in Polish)

27. I. Pasiecznik, M. Mańczak, W. Szczepaniak, The effect of sulphate ions on boron removal from water solutions (Polish environmental engineering five year after the access to the European Union, T. 1, 177-182, Lublin, 2009) (in Polish)

28. I. Pasiecznik, Boron removal from aqueous solutions in presence of sulphate ions (Interdisciplinary Problems in Environmental and Protection Enginnering, Publishing House of the Wrocław University of Technology, 325-332, Wrocław, 2011) (in Polish) 